\title{
Rockefeller denies work pressures led to 'poisoning' of researchers
}

New York. Rockefeller University in New York, one of the world's leading research universities, has been forced to defend itself against charges that excessive work pressure on postdoctoral students led to a bizarre incident in which one student is thought to have 'poisoned' the coffee of a dozen academic colleagues.

The incident took place in June in the laboratory of Robert Roeder, a molecular biologist whose research group is investigating the mechanisms of transcription. It was followed the next evening by the discovery that gas to all the laboratory's Bunsen burners had been switched on, but left unlit - and subsequently by a small fire in a stockroom and letters containing death threats being received by two female researchers.

Roeder himself also received threatening letters. The university called in the police to investigate and also increased security; all those entering the laboratory, for example, must now pass through a metal detector. But it had been hoping that the matter could be resolved internally.

Last week, however, the story was leaked to the Wall Street Journal. The normally staid financial newspaper carried a frontpage story under the attention-grabbing headline "Who's trying to kill the great biologists of Rockefeller U.?"

The story was quickly picked up by local papers in New York, many of which have since been providing daily embellishments based on information from police sources. (One prominent columnist described the "mad menace of Rockefeller University" as "the perfect summer story in Sin City".)

The original article detailed how several coffee-drinking researchers in the laboratory simultaneously experienced symptoms of diarrhoea and vomiting. The subsequent letters to the women researchers claimed this had been caused by sodium fluoride, known to be lethal at high dosages.

In describing this and the other incidents, the Wall Street Journal quoted a university official as suggesting that a possible contributory factor was tension among laboratory researchers caused by the continuous pressure to produce top-quality research.

Since then, however, other officials have moved to counter any impression that research staff in the laboratory - or indeed elsewhere at Rockefeller, which has in re-

\section{'Drive is from within', say scientists}

The following letter has been received by Nature from research, administrative and technical staff in Robert Roeder's laboratory at Rockefeller University:

Sir-Many of your readers are aware of a series of disruptive incidents that have occurred within the laboratory of Dr Robert Roeder at the Rockefeller University. As members of Roeder's group, we felt it necessary to address, especially to the scientific community, the provocative and unfair statements made in the media about our laboratory

Our laboratory has done, and continues to do, outstanding work in the area of transcription. Like any major laboratory competing in a 'hot topic' there are pressures, most of them arising from our own drive and ambition. The competitive environment in which we work in no way justifies the destructive acts perpetrated against our laboratory. Most of us conduct our research in an atmosphere of considerable collegiality, cooperation and friendship. While it is true, as in any large group of people, that there are occasional disagreements, reports of huge fights or racial tension are completely false.

The success of our laboratory can in large part be attributed to our mentor's determination and support. While Roeder is demanding, he is no harder on those who work with him than he is upon himself, and he has been very generous in providing an excellent environment in which to carry out research. We believe that the past and present record of scientific productivity of our laboratory speaks most eloquently for the work environment.

Any suggestion that the incidents that have occurred are somehow justified by the laboratory environment is ridiculous. A profoundly disturbed individual has chosen illegal and destructive means to solve his or her personal problems, disrupting the lives and work of the people in our laboratory. We hope that we can be judged on the basis of our record of scientific achievements and not unattributed aspersions cast in the popular press.

Sean Stevens, hut Ge, Thomas Oelgeschlager, Franck Brunel, Xiaolu Shi, Tae Kook Kim, Yuriko SUzUKI, Luz Hermida, JosepH FoNDELL, SHWU-YUAN Wu, Marcus Kretzschmar, AleXander HoffmanN, Zhengxin Wang, Susumu Inamoto, Yoshiaki OHKuma, Camilo Parada, Ernest Martinez, Cheng-Ming Chiang, Yng-Ju Hsieh, Magda Carvalho, Dong Kun Lee, Yan Luo, Jong-Bok Yoon, Tsutomu Ohta, UnKyu Kim, Maria Popov, Richard Bernstein, amttabHa Chakrabarth, Beth Moorfield, Leanne Gonzalez, Jian-oing Huang, Carmen-Gloria Balmaceda, JefF DeJong, Lin BaI, Xiaohong Zhang, Mohamed Guermah

Rockefeller University, 1260 York Avenue, Box 166, New York, New York 10021, USA cent years been carrying out a wide reappraisal of the way it organizes research and of the powers of laboratory heads - are required to work any harder than at other leading research universities.

"I think it is unfair that Roeder should be pointed out as some villain in this," says Torsten Wiesel, the 1981 Nobel prizewinner in medicine, who took over as president of Rockefeller two years ago following the resignation of the molecular biologist David Baltimore.

Wiesel says there is "a certain intensity to one's activity" in all laboratories that are "serious" about science. "We are all under pressure to produce interesting results," he says. "This is part of the reality of life."

The researchers in the laboratory have also jumped to Roeder's defence. A letter to Nature signed by almost 40 postdoctoral researchers, postgraduate students and other staff (see panel) acknowledges that pressures exist in Roeder's department. But it claims that most of them "are derived from our own drive and ambition".

Sean Stevens, the main organizer of the letter, says that the signatories are keen to show that "it is not us, it is not the research we do, and it is not the laboratory" that have been responsible for the recent events. $\mathrm{He}$ challenges statements in the press from an unnamed former researcher that Roeder's abrasive manner had led to "huge fights in [his] laboratory".

Since the original newspaper articles appeared, attention has shifted from work pressure to the more familiar territory of personal relationships. Last Thursday (28 July), the police confirmed that, largely on the basis of a psychological profile of the perpetrator, their main suspect was a foreign postgraduate researcher whose approaches had apparently been spurned by one of the women who received a death threat - and who felt that he was being ignored by the other.

Although a DNA test failed to match a saliva sample taken from one of the letters containing the threat to the suspect, police authorities said on Monday that they remain confident in their identification, and that "the investigation is continuing" in the search for firm confirmation.

Wiesel says he is confident that the incident will not harm the reputation of the university. "This might have happened anywhere," says Wiesel. "Next time, it might be in Cambridge, England." But with no firm confirmation of the perpetrator - and at least one researcher claiming she is now scared to come into the laboratory tensions remain high.

David Dickson 